\title{
Towards the median economic crisis voter? The new leftist economic agenda of the Front National in France
}

\author{
Gilles Ivaldi \\ URMIS, CNRS-Université de Nice Sophia Antipolis \\ gilles.ivaldi@unice.fr
}

\begin{abstract}
The Front national (FN) has made an impressive come back into France's electoral politics since 2012. Adopting a supply-side approach, this paper places the electoral rejuvenation of the FN in the context of the global crisis and looks at how the party has adapted programmatically to socio-economic demands emerging from this context. Based on manifesto data analysis, it finds that despite having recently broadened its economic programme, the FN maintains a niche status in the party system. The findings show however that the party has significantly shifted its economic platform, moving from a predominantly right-wing to a left-wing location since the mid-1980s. This move is characterized by an increase in egalitarian and nationalist economic policies, espousing also a populist framework. The reconfiguration of the FN suggests that the party may have moved to a pivotal position in recent years by converging around the economic preferences of the median voter. The paper discusses the role of internal and external factors in explaining the economic policy shift by the FN, and considers possible implications of these findings for understanding current populist radical right electoral dynamics in Europe.
\end{abstract}

\section{Keywords}

Front national, economic policy, party position, manifesto, global crisis, median voter, radical right

This is a post-peer-review, pre-copyedit version of an article published in French Politics in 2015. The definitive publisher-authenticated version Ivaldi, G. Fr Polit (2015) 13: 346. https://doi.org/10.1057/fp.2015.17 is available online at:

https://link.springer.com/article/10.1057/fp.2015.17 
Recently, the Front national (FN) has made an impressive come back into France's electoral politics, which attests to the political revitalization of the French populist radical right (PRR). In the 2012 presidential election, Marine Le Pen achieved her party's best performance ever in a first-order election with 17.9 per cent of the vote and just under 6.5 million votes. The FN made significant advances in the 2014 municipal elections where it eclipsed its 2008 setback by winning eleven city councils and over 1,500 local councillors. In the 2014 European elections, the FN scored a historic victory, symbolically emerging as first party with a quarter of the popular vote and 24 MEPs. This success was reiterated in the first round of the 2015 departmental elections where the party won 25.2 per cent of the vote nationally.

Explanations of PRR parties' electoral fortunes commonly include both demand and supplyside factors, that is, on the one hand, the preferences expressed by voters and, on the other hand, the way in which political parties respond to those expectations and concerns (Mudde, 2007; Arzheimer, 2009; Gómez-Reino and Llamazares, 2013). As Mudde (2007) points out: "a demand for populist radical right politics does not necessarily result in its emergence and success at the party system level. The supply-side translates demand into practical party politics" (p.202). Kitschelt (1995) argues similarly that the rise of the radical right is not just conditioned by favourable opportunity structures and existing demands for PRR alternatives, but also "by the capabilities and choices of the incipient rightist entrepreneurs and parties themselves" (p.3). The success of PRR parties is contingent on their ability to fashion appropriate policy appeals to voters under a given set of structural conditions. The position they take in the competitive space may produce different electoral constituencies and different 'yield ratios' within the electorate (Kitschelt, 1995, p.18). In his cross-national examination of populist parties, Van Kessel (2013) emphasizes also the importance of those parties' own agency and electoral credibility as vital factors in explaining their election performances.

Looking at the FN's recent electoral recovery, internal changes embedded in Marine Le Pen's strategy of 'de-demonization' have helped improve the party's reputation. Changes are perceptible across a range of public opinion indicators, which include an increase in popularity for both the party and its leader since 2011, a growth in public support for the FN's ideas -most strikingly among right-wing voters-, as well as a substantial drop in perceptions of the party as a threat to French democracy since the mid-1990s (Ivaldi, 2015). The softening of the FN's rhetoric has allowed the party to expand its electoral base beyond its former core support. Recent analysis by Mayer (2013) shows the disappearance of the electoral gender gap which was characteristic of the French radical right. The FN is draining also greater support from younger voters (Stockemer and Amengay, this issue). Externally, the electoral revival of the FN must be placed in the broader context of the current economic crisis. The crisis and its ramifications both social and political have created a favourable structure of opportunity for populist parties such as the FN. Since 2008, France has experienced a rise in unemployment, sluggish economic growth and degraded public debt, combined with new taxes and spending cuts (Heyer et al, 2013). The management of the Eurozone crisis through fiscal consolidation and austerity packages has fuelled public discontent with both the national government and the EU (Hobolt and Tilley, 2013).

Like other west-European populist radical right parties, however, the FN confronts new policy incentives emerging from the crisis. The recession has shifted the electoral agenda towards the economy, resulting in a significant increase in salience of financial and economic management issues (Singer, 2013). The crisis has also substantially augmented public support for redistribution and economic regulation (Olivera, 2014), challenging the traditionally more market liberal agenda of PRR parties. The latter may choose to adjust their policies to 
maximize electoral support, possibly reflecting shifts in voter economic preferences and changes in structural conditions.

This paper explores the FN's programmatic response to the global economic crisis. It concentrates predominantly on the internal supply-side of the PRR. We look more specifically at how the party has adapted its economic strategy to this changing environment. In doing so, we focus on one supply factor exclusively, namely economics, which represents an important area of policy change by the FN. The first section places the FN in the context of the PRR economic literature by looking at aspects of salience, position and policy dispersion. The paper then turns to describing the data and the methodology employed for content analysis of FN programmes and their contextualisation since the early 1980s. The results show that despite augmenting the salience of its economic programme in recent years, the FN maintains a distinctive niche profile in the French party system. The party has significantly modified its economic position since the mid-1980s however, moving from a predominantly right-wing to a left-wing location, which suggests convergence around the preferences of the French median economic voter in the current crisis. The final section explores the set of internal and external factors behind the FN's economic policy shift, and considers possible implications of our findings for the understanding of current populist radical right electoral dynamics in Europe.

\section{The PRR and the economy}

The general consensus among scholars is that PRR parties share a common 'niche' sociocultural agenda which emphasizes a narrow set of cultural issues while de-emphasizing economic concerns (Rydgren, 2005; Meguid, 2008; Wagner, 2012a). Mudde (2007) argues for instance that economic issues are both 'secondary' and 'instrumental' to the PRR, and that they proceed mainly from the nativist and authoritarian core of its ideology (p.132). Similarly, Rovny (2013) makes the case that those parties tend to emphasize non-economic issues while muting economic ones. A niche status should not be regarded as a fixed feature however, but should rather be treated as a 'fluid' characteristic and a dimension of programmatic change (Wagner, 2012a, p.847). The current economic crisis may provide incentives for PRR actors to try and modify their salience strategy. They might decide to give more weight to the economy and to present also more responsible policies to gain economic credibility. Increasingly complex issues of economic governance represent a challenge for the PRR, inviting those parties to revisit their socio-economic approach and making it more difficult to turn their eyes away from national debates of fiscal rectitude, economic growth or debt reduction. PRR parties may therefore face a strategic trade-off between responsible economic positions, on the one hand, and a populist strategy that would allow them to capitalize on mainstream party failure to address the economic crisis, on the other hand.

A second aspect concerns the economic location of PRR parties. The latter have displayed a good deal of economic policy instability over time (Betz, 1996). During the 1980s, parties such as the FN were associated with neoliberal economics and a backlash against bureaucracy and the welfare state (Betz, 1994; Ignazi, 2003; Kitschelt, 1995). Most scholars agree however that they have progressively adopted a more 'centrist' position on the economic axis (McGann and Kitschelt, 2005; De Lange, 2007), reflecting the diversification of their electoral base and the growth in blue-collar support. Mudde suggests that PRR parties have disengaged from neo-liberalism and moved closer to social market economy (2007, p.124). During the same period, some of them have emerged as strong opponents of economic 
globalization, neo-liberalism and European integration (Betz, 2002; Bornschier, 2005; Zaslove, 2008).

There is little knowledge of the economic location of the PRR in the current crisis. These parties may take diverging routes. While some continue to uphold market liberalism, others might adopt more traditional statist positions and turn to social issues. Diverging PRR responses to the crisis might be conditioned by shifts in the median voter economic preferences. Winning PRR strategies may no longer be confined to the capitalist-authoritarian sector of the competitive space. Recent research suggests that significant sectors of the West European electorate cluster around positions combining left-wing economics with sociocultural authoritarianism, which have the potential to create a new successful location for the PRR (Van der Brug and Van Spanje, 2009; Lefkofridi et al, 2014). Betz and Meret (2013) see right-wing populist parties such as the FN moving in that direction. They argue that those parties increasingly advance leftist socio-economic solutions and present voters -particularly in the lower social strata- with an ideological mix of cultural nativism and economic populism (p.121).

This takes us to the last question which concerns the programmatic variance in the PRR, that is the variation in the distribution of their policies on the economic axis. PRR actors are more likely to present vague and multiple economic policy positions (Rovny, 2013, p.8). The uncertainty regarding the economic whereabouts of PRR parties stems from the fact that they exhibit heterogeneous mixes of policy preferences. Achterberg et al (2011) suggest for instance that the PRR combines economic egalitarianism and anti-welfare chauvinism to mobilize support from voters in the lower social strata. Rovny (2013) claims that those parties tend to deliberately 'blur' their positions on economic issues to attract broader electoral support. These parties present antagonistic economic positions and their voters hold significantly more dispersed economic views (Ivarsflaten, 2005). There might also be some variation in their positions across policy sub-areas -i.e. welfare and social issues and macroeconomic management- or domains of economic intervention -i.e. national vs international. Betz and Meret (2013) argue for instance that right-wing populists promote laissez-faire liberalism in the domestic market while advocating economic nationalist positions in the international sphere (p.115). Otjes et al (2012) suggest to distinguish between clusters of economic positions which can be combined with right-wing populism, namely 'economic liberalism', 'economic egalitarianism', 'economic nationalism' and the 'deserving poor' (pp.4/5).

\section{Data and methods}

The FN's economic strategies are examined by considering attributes of policy salience, position and dispersion. The literature on party competition suggests that political parties make decisions regarding the positions they take on issues (Wagner, 2012b). Parties can also manipulate the salience of issue dimensions in the pursuit of electoral gains (Meguid, 2005, p.349; Rovny, 2013, p.4). With regards to the PRR, an additional attribute worth of consideration is that of policy variance and the extent to which those parties combine conflicting positions on the economic axis. 
Our data are drawn from party legislative platforms over the 1981-2012 period (see Appendix 1). Analysis of party manifestos is widely employed in the literature and it is acknowledged for its higher degree of impartiality (Marks, 2007). Party manifestos are considered authoritative policy statements and reliable textual sources of information about the policy emphases and positions of political parties. The period of time covered here corresponds with the lifespan of the FN before and immediately after its 1984 electoral breakthrough, leaving aside its years as politically irrelevant actor during the 1970s.

The operationalization of the economic dimension in this paper follows the classic model of polarity between the state and market. Kitschelt (1994) defines this opposition as a conflict between 'socialist' and 'capitalist' economics. According to the French traditions of political conflict, these two poles can be characterized as 'left' and 'right'. The former pole of the axis concerns demand-side economics based on state intervention in the economy, more social spending for welfare or higher progressive redistributive taxation. The capitalist-right pole represents on the other hand liberal competitive and free market supply-side economics, favoring lower taxes, smaller government and the deregulation of the economy (see Appendix 2). This construction corresponds to standard policy measures and expert estimates of party economic positions (Budge et al, 2001; Hooghe et al, 2010).

To test first changes in FN economic salience strategy, this paper uses the Comparative Manifesto Project (CMP) data for France. CMP data provide party specific measures of the relative salience of political issues in party platforms across time (Budge et al, 2001). The original CMP dataset is complemented with the coding of the FN's legislative platforms of 1981, 1988 and 1993 which are missing in the CMP series, and whose values have been previously imputed via interpolation ${ }^{1}$.

The methods and criteria to establish the economic salience profile of the FN relative to the other actors in the French party system draw on the approach by Meyer and Wagner (2013). To have a PRR niche status, a party should meet all following criteria: 1/ a high emphasis on socio-cultural issues compared to its competitors; 2 / a high general party emphasis on sociocultural issues (at least 10 per cent of its manifesto); 3/ a low emphasis on economic policy compared to its competitors. This dichotomous approach to party nicheness is preferred to other continuous measurement alternatives (Meyer and Miller, 2015), as it provides clear cutoff values to establish whether a party is indeed breaking away from its niche location. As a rule of thumb, a party de/emphasizes an issue more than its competitors if its salience is at least one weighted standard deviation below/above the mean party system salience. Party system salience is calculated for all parties other than the FN, and it is weighted by votes. Appendix 3 shows the assignment of CMP issue categories into the main aggregate economic and socio-cultural issue areas.

To examine the FN's economic positions, we use an original collection of data based on a directional content analysis of the party's manifestos since 1981. This second dataset elaborates on the principles of the 'confrontational' approach to manual content analysis (Pellikaan et al, 2003; Kriesi et al, 2006). Here, the basic coding unit is the individual policy proposal or pledge. Pledges are valid and substantive indicators of the policy positions taken by parties. They reflect "the specific policy commitments that parties make in their election manifestos" (Akkerman, 2015, p.59). The analysis is restricted to 'hard pledges' and ignores

\footnotetext{
${ }^{1}$ Due to the length of the $1993 \mathrm{FN}$ manifesto, we use the paragraph rather than the quasi-sentence as a unit for counting policy statements, a procedure consistent with previous CMP coding of party documents in France (Brouard et al. 2012: 260).
} 
soft pledges or more general policy statements. This dataset concerns economic policies as well as other social or cultural policies with a clear economic implication and, in the vast majority of cases, unambiguous direction.

Policy pledges are coded on a simple dichotomous economic variable (Left $=-1$; Right $=+1$ ). Individual pledges are coded only once in cases of multiple occurrences in the reference text and they are arbitrarily given the same weight. The use of complete data reduces selection bias in directional models based on small subset of specific issues deemed representative of latent dimensions (Pellikaan et al, 2003, p.33). Problems concerning the reliability of data and the validity of their interpretations are inherent in qualitative data coding (Crittenden and Hill, 1971). Here the presence of a single coder (the author) does not allow for inter-coder reliability testing. To improve coding consistency, however, a unique ID is attributed to each individual policy pledge, which allows also to trace changes in issue positions over time.

For the purpose of the analysis, the economic dimension is broken down into two separate sub-scales. The first is dedicated to welfare, concerning such issues as social justice, healthcare, education, pensions and social security. The second sub-scale relates to macro and micro-economic issues. It concerns economic regulation, tax policies, economic incentives, the role of the state, and more generally models of economic governance (see Appendix 4).

The data consist of $689 \mathrm{FN}$ economic policy pledges between 1981 and $2012^{2}$. Economic and welfare positions are estimated by computing ratio scales of left and right policies based on relative proportional difference (Lowe et al, 2011) ${ }^{3}$. A general index of economic position is calculated from the aggregation of the above two dimensions using the same procedure.

Co-opting Otjes et al (2012), the data are also broken down into three clusters of economic policies ${ }^{4}$. The first cluster refers to 'economic liberalism' which supports small government, free market, welfare retrenchment and tax cuts. The second cluster concerns 'economic egalitarianism' and consists of all policy pledges that advocate redistribution, economic regulation and the defense of public services. The last cluster refers to 'economic nationalism' which seeks to protect national interests against external threats e.g. immigration, globalization, the EU. While economic egalitarianism and liberalism overlap with our definition of 'left' and 'right', the mix of economic nationalism and egalitarianism is of particular interest to the characterization of change in $\mathrm{FN}$ economics.

Finally, we return to CMP data to contextualize findings from the directional analysis. Whilst predominantly based on salience, the CMP material is also a dominant data source for the estimation of party positions. Each issue reflects a party's concern with some specific policy area and with direction of such policy (McDonald and Mendes, 2001; Benoit and Laver 2012). Different methods have been suggested to scale continuous policy positions from

\footnotetext{
${ }^{2}$ A total of 25 economic policy statements were removed from the analysis. These were cases where no clear left-right direction could be attributed -e.g. "we will renegotiate fiscal conventions with our foreign partners" (2012).

${ }^{3}$ The FN position is calculated as the difference between right-wing and left-wing economic policies divided by their sum in each manifesto $(\mathrm{R}-\mathrm{L}) /(\mathrm{R}+\mathrm{L})$, which in this case is equivalent to computing the arithmetic mean. A negative score indicates therefore a leftist position, while a positive score indicates a rightist position on the economic dimension.

${ }^{4}$ Let us note here that Otjes et al (2012) distinguish an additional fourth cluster of economic policies directed at the 'deserving poor' i.e. poor members of society who 'truly' deserve welfare support because they are unable to provide for themselves. This cluster concerns only a minority of the FN's policies and is therefore not included in this analysis.
} 
political text coded into discrete categories (König, 2013). Here we employ the additive index based upon the economic policy scale constructed by Benoit and Laver $\left(2007\right.$, p.100) ${ }^{5}$. As was the case for directional pledge data, the ratio score method is preferred to other procedures of item summation (Lowe et al, 2011) ${ }^{6}$.

For each election year, the position of the median economic voter is computed using the methodology introduced by Kim and Fording (1998) in relation with the CMP data. This position is obtained from vote shares for ideologically ranked parties on the aforementioned economic policy scale (p.79). We exclude other possible data sources concerning the policy positions of French parties such as the Chapel Hill Expert Survey which only covers the period since the late 1990s and does not provide policy estimates for the most recent 2012 elections.

Following the recommendations by Benoit et al, (2009, p.497), we generate associated measures of uncertainty for all policy estimates by computing bootstrapped $95 \%$ confidence intervals $(\mathrm{N}=1,000$ iterations). Party policy positions are taken from mean estimators of the bootstrap simulations.

\section{Empirical results: a new economic profile for the FN?}

The economic and socio-cultural salience profiles of the FN relative to the other actors in the French party system are summarized in Table 1 . The mean party system salience of economic and cultural issues in Table 1 refers to the weighted average salience of those two issue areas -as percentages of manifestos devoted to those issues- for all parties in the system but the FN. Table 1 shows also the standard deviation for the party system at each election year. All estimates are obtained from bootstrap simulations and they are provided with $95 \%$ confidence intervals.

Our data reveal that the FN has recently assigned greater programmatic importance to economic issues, while de-emphasizing its cultural agenda. In 2012, the size of its economic portfolio exceeded that of its traditional cultural policies. Economic issues of household income, the Euro, employment, public debt, pensions and taxes were brought to the front of the party's presidential platform, reflecting the diversification of its policy package ${ }^{7}$. The attempt by the FN to broaden its issue appeal is by no means new. During the 1990s, the mégrétiste modernist faction had already attempted to profile the $\mathrm{FN}$ as a credible governmental alternative. A similar salience strategy was visible in the 1993 election manifesto. On both occasions, valence shifts by the FN corresponded also with periods of economic recession and higher unemployment, which suggests that PRR actors may adjust their economic salience profile to adapt to the deterioration of the socio-economic environment.

\footnotetext{
${ }^{5}$ Benoit and Laver (2007:100) define their economic policy ratio scale for the CMP data: Left econ. $=$ PER $(403$ $+404+406+412+413+504+506+701)$; Right econ. $=$ PER $(401+402+407+414+505)$.

${ }^{6} \mathrm{FN}$ policy estimates from the pledge-based directional analysis are validated externally through the use of CMP data. Correlation between the two measures of economic positions is 0.8 at $p<0.01$ ( $N=8$ elections since 1981) (see Appendix 5).

${ }^{7}$ As stated by Marine Le Pen: "I am standing on my own two legs. On the one hand, unemployment, public debt and purchasing power. On the other hand, immigration and insecurity" (TF1, 6 March 2012).
} 
Table 1. Changes in the FN's economic and sociocultural salience profile and economic indicators

\begin{tabular}{|c|c|c|c|c|c|c|}
\hline \multirow[b]{2}{*}{ Year } & \multicolumn{4}{|c|}{ Economic issues } & \multicolumn{2}{|c|}{ Economic indicators } \\
\hline & $\begin{array}{c}\text { Mean party } \\
\text { system } \\
\text { salience }\end{array}$ & $\begin{array}{l}\text { Standard } \\
\text { deviation }\end{array}$ & FN salience & Niche & $\begin{array}{l}\% \text { GDP } \\
\text { growth }\end{array}$ & $\begin{array}{l}\text { \% unem- } \\
\text { ployment }\end{array}$ \\
\hline 1981 & $\begin{array}{c}37.9 \\
(34.1-41.8)\end{array}$ & $\begin{array}{c}14.4 \\
(9.9-19.0)\end{array}$ & $\begin{array}{c}26.8 \\
(17.3-36.5)\end{array}$ & No & 1.0 & 6.3 \\
\hline 1986 & $\begin{array}{c}43.0 \\
(38.4-47.6)\end{array}$ & $\begin{array}{c}10.4 \\
(5.9-14.8)\end{array}$ & $\begin{array}{c}14.2 \\
(9.1-20.3)\end{array}$ & Yes & 2.3 & 8.9 \\
\hline 1988 & $\begin{array}{c}40.2 \\
(35.5-45.0)\end{array}$ & $\begin{array}{c}12.0 \\
(7.2-16.8)\end{array}$ & $\begin{array}{c}24.1 \\
(15.5-34.5)\end{array}$ & Yes & 4.7 & 8.8 \\
\hline 1993 & $\begin{array}{c}47.3 \\
(43.2-51.6)\end{array}$ & $\begin{array}{c}10.3 \\
(6.2-14.7)\end{array}$ & $\begin{array}{c}30.5 \\
(17.6-42.6)\end{array}$ & Yes & -0.7 & 10.0 \\
\hline 1997 & $\begin{array}{c}27.4 \\
(23.8-31.3)\end{array}$ & $\begin{array}{c}6.8 \\
(4.3-9.5)\end{array}$ & $\begin{array}{c}16.0 \\
(9.3-22.7)\end{array}$ & Yes & 2.2 & 10.7 \\
\hline 2002 & $\begin{array}{c}30.8 \\
(27.7-34.0)\end{array}$ & $\begin{array}{c}5.0 \\
(3.1-7.2)\end{array}$ & $\begin{array}{c}28.2 \\
(22.8-34.0)\end{array}$ & No & 0.9 & 7.9 \\
\hline 2007 & $\begin{array}{c}38.8 \\
(33.2-44.6)\end{array}$ & $\begin{array}{c}5.1 \\
(1.9-9.7)\end{array}$ & $\begin{array}{c}23.2 \\
(15.0-33.9)\end{array}$ & Yes & 2.3 & 8.0 \\
\hline 2012 & $\begin{array}{c}47.0 \\
(43.7-50.5)\end{array}$ & $\begin{array}{c}4.6 \\
(2.6-7.0)\end{array}$ & $\begin{array}{c}36.7 \\
(31.3-42.1)\end{array}$ & Yes & 0.0 & 9.8 \\
\hline
\end{tabular}

\begin{tabular}{l|ccccc}
\hline & \multicolumn{5}{|c}{ Socio-cultural issues } \\
\hline \multirow{5}{*}{ Year } & $\begin{array}{c}\text { Mean party } \\
\text { system }\end{array}$ & $\begin{array}{c}\text { Standard } \\
\text { deviation }\end{array}$ & $\begin{array}{c}\text { FN } \\
\text { salience }\end{array}$ & Niche & $>10 \%$ \\
\hline \multirow{5}{*}{1981} & 6.8 & 4.6 & 36.1 & Yes & Yes \\
& $(4.8-9.2)$ & $(3.2-6.3)$ & $(25.0-48.1)$ & & \\
1986 & 10.0 & 6.1 & 23.5 & Yes & Yes \\
& $(7.4-13.0)$ & $(4.1-8.9)$ & $(16.7-30.6)$ & & \\
1993 & 7.6 & 5.6 & 40.0 & Yes & Yes \\
& $(5.2-10.3)$ & $(3.7-7.8)$ & $(29.3-51.7)$ & & \\
2002 & 2.0 & 2.1 & 23.2 & Yes & Yes \\
& $(1.0-3.1)$ & $(1.0-3.5)$ & $(12.5-35.0)$ & & \\
& 5.7 & 3.2 & 44.2 & Yes & Yes \\
& $(3.7-7.9)$ & $(1.4-5.5)$ & $(36.0-53.3)$ & & \\
2007 & 16.8 & 5.3 & 28.6 & Yes & Yes \\
& $(14.0-19.6)$ & $(3.0-7.8)$ & $(23.1-34.3)$ & & \\
& 9.6 & 3.8 & 27.5 & Yes & Yes \\
& $(6.5-12.6)$ & $(2.7-5.4)$ & $(18.8-37.6)$ & & \\
& 9.4 & 6.2 & 27.6 & Yes & Yes \\
\hline
\end{tabular}

Source: CMP data. Author's additional coding for FN in 1981, 1988 and 1993.

Salience data weighted by $\%$ of the national vote as provided in the CMP dataset

Bootstrapped estimates ( $\mathrm{N}=1,000$ iterations), $95 \%$ CIs between brackets

INSEE. Unemployment: http://www.insee.fr/fr/themes/tableau.asp?reg id=0\&ref id=NATnon03337

GDP: http://www.insee.fr/fr/themes/tableau.asp?reg id=0\&id=159 
The deficit in economic salience remains larger than the weighted standard deviation in the French party system however. Confidence intervals show also that the increase in economic salience would fail to achieve significance. Moreover, in party system terms, the FN has maintained a distinctive niche status in 2012, which is characterized by significantly greater socio-cultural salience compared to other French parties. Whilst moving towards mainstream economic salience, the FN continues to differentiate its policy agenda from other competitors on the socio-cultural dimension, which suggests that the party continues seeking to maximize electoral opportunities for populist radical right politics.

Turning to positions, the directional analysis shows that the FN has gradually -and significantly- shifted its economic platform, moving from a predominantly right-wing to a left-wing location since the mid-1980s. Estimated FN moves on the economic dimension over time are plotted in Figure 1. The dotted line shows the mean economic policy position of the $\mathrm{FN}$ on the scale ranging from -1 (left) to +1 (right), which is constructed from the relative proportional difference of left and right economic policy pledges in each FN manifesto. Error bands around the estimates represent $95 \%$ confidence interval.

As can be seen, the size of error bands in Figure 1 suggests a significant amount of variance over time, particularly in the 1981, 1988 and 1997 manifestos where standard errors are larger due in part to the smaller size of party documents. Contrary to conventional academic wisdom, however, disaggregating the economic dimension into welfare and economic management sub-areas shows that this leftward move is most evident in the positions taken by the FN vis-à-vis macro and micro economic issues, whereas changes in the party's welfare policies are less clear prior to 2012. This is exemplified in Figure 2 which shows FN economic position data according to policy sub-domain, based on the same measurement procedure as above. We find a higher level of variance in the welfare policy area, which suggests that the party has been continuously balancing social-protectionist policies with its more traditional agenda of welfare retrenchment.

Figure 1. FN economic positions (1981-2012)

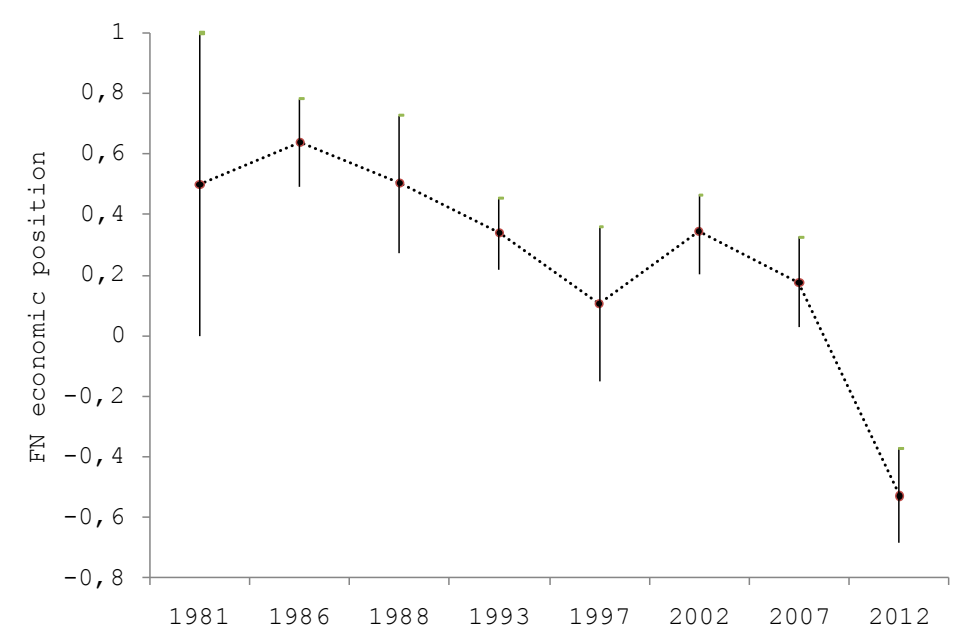

Dotted line is the mean economic position of the FN for each election year; bars indicate bootstrapped $95 \%$ confidence intervals around these estimates

Data from the directional analysis of policy pledges, economic index $\mathrm{N}=689$. 
Our findings are in line with the literature on PRR economics for the earlier periods. They support Kitschelt's (1995) hypothesis of a 'winning formula' during the entry phase of the West European PRR, which defines the PRR as strong advocate of rightist free market economics, small government and deregulation. The FN's capitalist appeal culminated in the 1986 and 1988 legislatives where the vast majority of its macro economic policies were located to the right (see Figure 2). Let us also note here that comparable data for the 1984 European election manifesto, which are not included here, corroborate the right-wing economic profile of the FN at time of electoral breakthrough ${ }^{8}$.

Figure 2. FN economic positions by policy sub-domains (1981-2012)

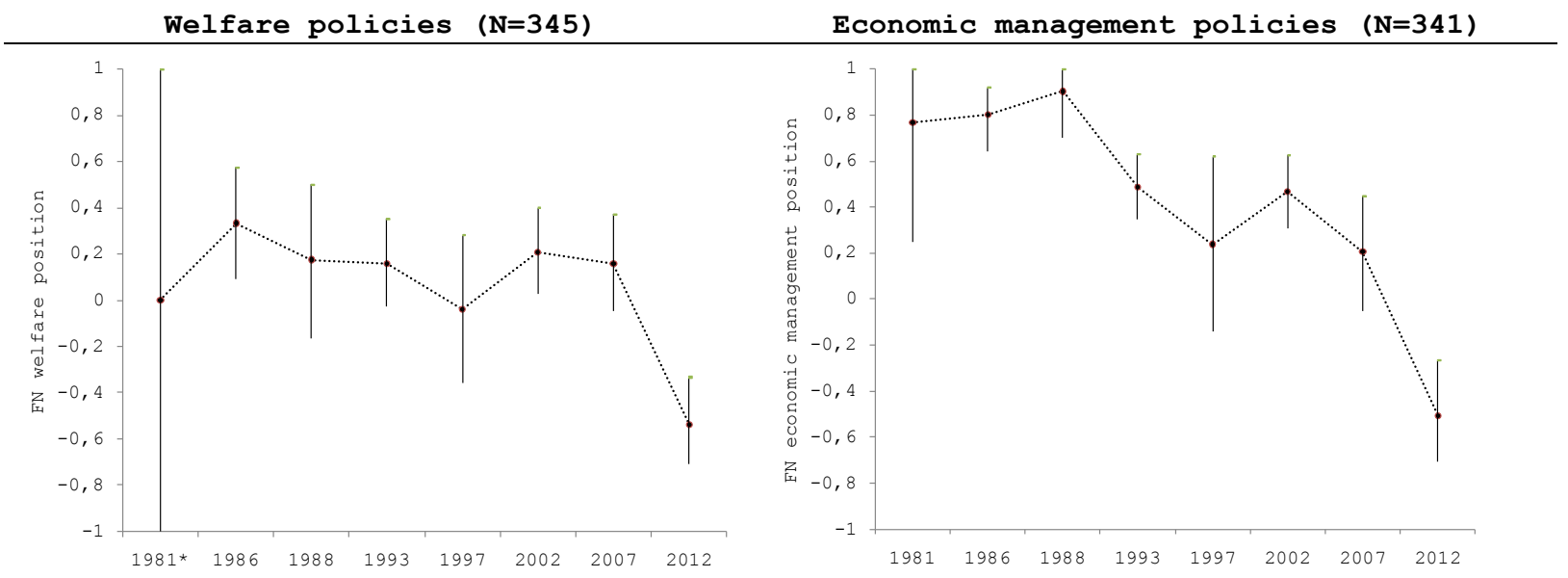

Dotted line is the mean position of the FN for each election year; bars indicate bootstrapped $95 \%$ confidence intervals around these estimates

Data from the directional analysis of policy pledges; sub-welfare index $\mathrm{N}=345$; sub-economic index $\mathrm{N}=341$

*1981: the welfare dimension should not be interpreted because of small sample size ( $\mathrm{N}=4$ with a 50/50 split).

The data indicate that a first significant programmatic shift occurred in the mid-1990s, which is characterized by a substantial revision of the party's neoliberal policies. These findings confirm McGann and Kitschelt's hypothesis of a 'weak' form of the new radical-right formula that has a muted appeal to free-market liberalism $(2005$, p.150). They corroborate also De Lange (2007) who shows that, during the 1990s, PRR parties "have indeed taken a position in the competitive space that is economically centrist in orientation" (p.428). As can be seen from our FN data, the overall proportion of rightist economic policies fell notably between 1988 and 1997. Reflecting the consolidation of its working-class support (Perrineau, 1995), the party endorsed also new themes of social protection and welfare, as resumed in its 1993 campaign motto "social without socialism" (1993: 220), although our manifesto data show only movements of limited amplitude on welfare issues. The new 'centrist' orientation of the FN is best exemplified by the 1997 manifesto which contains an almost equal proportion of left and right socio-economic policies (46 and 54 per cent respectively). Middle-of-the-way economics persisted throughout the late 1990s and 2000s, with no significant variation between 1993 and 2007.

\footnotetext{
${ }^{8}$ Mean position in the 1984 EP elections was 0.57 within a bootstrapped 95\% CI [0.41 - 0.72] (N=79 socioeconomic policy pledges, source: Droite et démocratie économique (éd. 1984)).
} 
A last strategic shift took place in 2012, whereby the FN moved to a left-wing location on the economic axis. This move represents a significant departure from the party's previous rightist position on both the economic and welfare sub-domains. In 2012, over three quarters (76 per cent) of the party's socio-economic policies were located to the left. In spatial terms, the 2012 shift was also remarkable for its magnitude. Between 1981 and 2007, FN economic shifts were relatively modest and incremental at an average 0.2 policy units, with little variation across elections. In 2012, in addition to crossing the political rubicund, the economic policy shift was thrice in size that of the previous periods ( 0.7 policy units).

The finding of the changing economic nature of the FN period is reinforced by the variation in policy clusters -namely economic egalitarianism, liberalism and nationalism-over time.

Percentages of FN policies in each cluster of economic position, together with corresponding $95 \%$ confidence intervals, are displayed in Figure 3. Here the data are restricted to a subset of selected election years (i.e. 1986, 2002 and 2012) which are deemed representative of the main three 'phases' of FN economic development since the mid-1980s.

The data show an increase in economic nationalism, with no clear 'post-crisis' effect however as this shift was already discernible in the FN agenda of the early 2000s. As best exemplified by its promotion of a French exit from the Euro, the FN has progressively taken over antiglobalization, eurosceptic and protectionist policies, antagonizing its former free-trade and laissez-faire economics. Economic nationalism was cornerstone to the FN's 2014 European manifesto. The latter claimed that the FN would renationalise the CAP, stop the country's contribution to the European budget, introduce taxes at France's borders, stop all EU bailout plans, regulate the banking system, vote against the Transatlantic Trade and Investment Partnership (TTIP) and fight the Posting of Workers Directive. Since the outbreak of the global crisis, these policies have resonated with growing Eurosceptic sentiment and widespread globalization fears in the French electorate ${ }^{9}$.

${ }^{9}$ In 2014 , only $51 \%$ of the French said EU membership was a 'good thing' compared with $67 \%$ in 2004. 
Figure 3. FN economic positions by policy clusters (1986, 2002 and 2012)
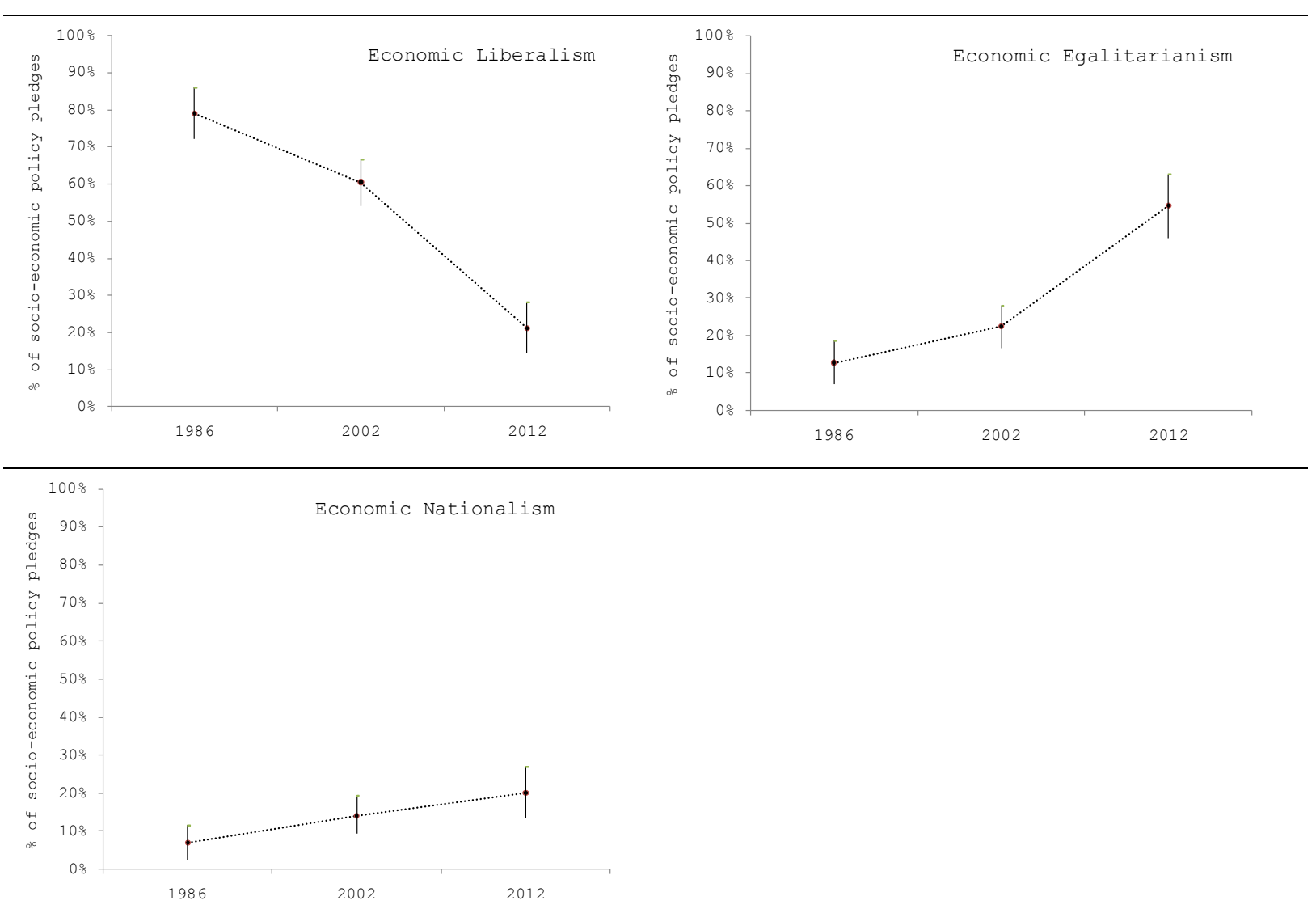

Dotted line is the \% of FN policies in a given economic cluster for each election year; bars indicate bootstrapped $95 \%$ confidence intervals around these estimates

Data from the directional analysis of policy pledges.

Changes are most perceptible in the cluster of economic egalitarianism which reveals a substantial increase in the proportion of redistributive and regulatory policies over time. Since 2012, the FN has taken up a 'Keynesian' domestic program of state regulation, government spending, and public services expansion, with a strong emphasis on income redistribution and purchasing power ${ }^{10}$. The data show a clear shift in the post-crisis period. These findings contradict the assumption that the PRR may have shifted to leftist economic policies in the international sphere -i.e. economic nationalism - while upholding free market liberalism in national politics. This new egalitarian socio-economic package has also become more autonomous from typical PRR welfare chauvinist values, while increasingly espousing populist arguments.

\footnotetext{
${ }^{10}$ The FN pledged for an increase in low wages, a control over commodity and food prices, as well as an increase in small pensions and in the minimum allowance for the elderly, and a return to 60 as retirement age. It advocated 'progressiveness and social justice' through higher taxes on the wealthiest, more progressive income tax bands, an increase in VAT for luxury goods, an increase in corporate taxes including a special tax on company relocations and the automatic adjustment of wages for inflation. The manifesto called also for the public control of banking and claimed that public services should be 'available to all', opposing the centre-right RGPP policy not to replace one in two civil servants going into retirement.
} 
The 2012 presidential campaign by the FN prioritized the so-called 'silent constituency' and all the 'invisible' at the 'bottom of society' (La France d'en-bas), opposing 'little' to 'big people' across all economic sectors ${ }^{11}$. This mobilization clearly resembles the 'racistauthoritarian strategy' described by Kitschelt (1995) as "the defence of income redistribution and of the 'little people' in the street against the large corporations and trusts" (p.22).

Finally, the data exhibit a marked decrease in economic liberalism over time. As suggested above, however, the FN economic platforms are characterized by policy variance. The more recent economic refashioning should not conceal the persistence of a small array of 'residual' right-wing liberal elements, making up about a fifth of the party's policies in 2012. The FN retains for instance its longstanding antipathy to labour unions or decentralization. It remains committed also to stigmatizing social welfare 'dependency' (assistanat) and benefit fraud ${ }^{12}$. Recent research suggests that economic egalitarianism and support for the welfare state may in fact form two distinct independent ideological dimensions, and that both are represented in the ideology of the PRR (Achterberg et al, 2011; De Koster et al, 2013). Neoliberal and welfare populist policies are core ideological features of the French radical right, therefore less amenable to change. Their presence, albeit residual, is directed at the more traditional petty-bourgeois clientele of the FN, and these policies represent also a reservoir for any possible economic recalibration of the party in the future.

\section{Towards the median economic voter?}

This takes us to the last question in this paper, which concerns the demand side of the FN's economic shift. As previously argued, PRR parties may adjust their socio-economic policies to maximize electoral support, thereby reflecting changes in pivotal voter economic preferences. Our findings suggest that the FN may be strategically adapting to electoral demands for social protection and economic redistribution in the current crisis.

In Figure 4, we return to FN left-right economic positions obtained from the directional analysis of policy pledges since the mid-1980s. This economic trajectory by the FN is plotted against changes in the position of the median economic voter over the same period of time. This position is calculated from Benoit and Laver's (2007) economic policy scale based on CMP data, which ranges similarly from -1 to +1 according to policy direction (left / right). We employ the formula by Kim and Fording (1998, p.79), which estimates the position of the median voter from vote shares for parties ranked on a given ideological dimension. Following the general procedure in this paper, we compute bootstrapped $95 \%$ confidence intervals for both sets of estimates.

\footnotetext{
${ }^{11}$ Marine Le Pen antagonized all the "powerful, representatives of the dominant 'globalist' (mondialiste) ideology: i.e. politicians, the European Commission, financial markets, CAC 40 companies, the 'super wealthy', the 'loutish businessmen' or large retail companies".

${ }^{12}$ In 2012, harsh criticism of benefit fraud was put to the forefront of the FN agenda of budgetary rigor and reduction in government spending. The FN claimed that a more efficient fight against social security 'cheaters' and those undeserving assistance would provide an additional $25 \mathrm{Bn}$ Euros in revenue to the French state. The party called also for the suppression of all social benefits to social fraud recidivists and all offenders sentenced to one year imprisonment or more.
} 
Put in context, our data show that the FN has consistently remained to the right of the economic voter but has recently converged around the position of the median economic voter, which was firmly anchored to the left of the economic axis in the 2012 elections (see Figure 4). Similar moves occurred in 1986 and 1997. This suggests that both the 'market liberal' and 'centrist' positional shifts of the mid-1980s and mid-1990s were strategic adjustments by the FN, possibly corresponding to changes in voter economic preferences. Shorter-term variation in the FN's policy shifts indicates also that the party has adapted its economic strategies to changes in its political environment over time. With the exception of the 1993 legislatives, all FN economic policy shifts between election have gone against the political color of the incumbent.

Figure 4. FN economic position and median economic voter (1981-2012)

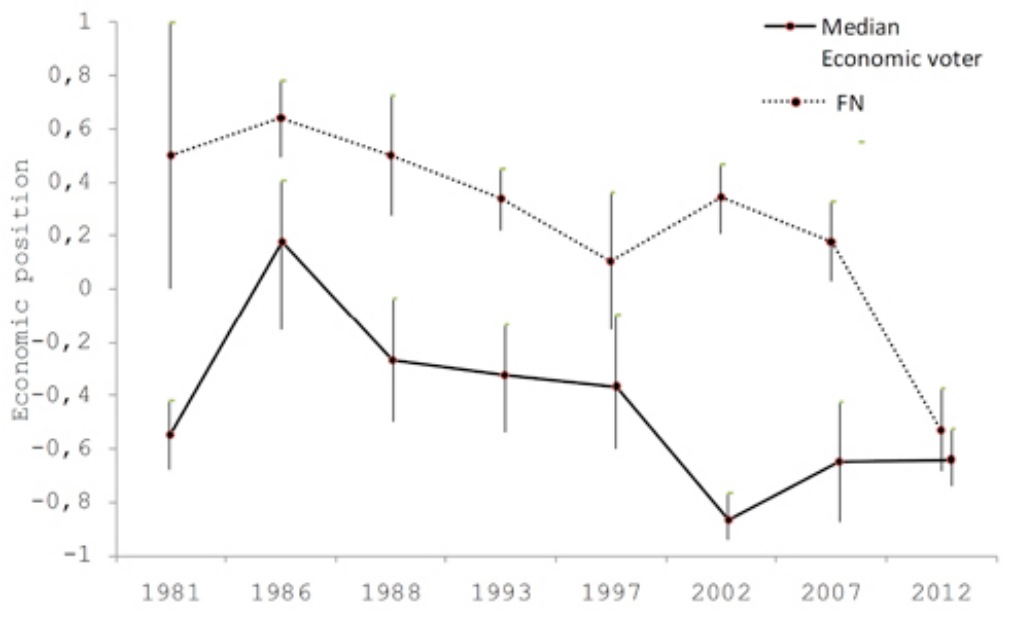

Dotted line is the mean economic position of the FN for each election year; solid line is the position of the median economic voter; bars indicate bootstrapped 95\% confidence intervals around these estimates. FN data is taken from the directional analysis of policy pledges; the median economic voter position is computed from CMP data using Kim and Fording (1998, p.79) formula.

Our data corroborate recent analysis of voting behavior in France. In his longitudinal study of the impact of cultural and socio-economic values on voting, Tiberj (2013) finds for instance that FN voters in the mid-1980s corresponded to the 'authoritarian-capitalist' type described by Kitschelt (1995). In contrast, his results show that the probability of voting for the FN in 2012 increased substantially among culturally conservative voters who had also high levels of economic conservatism. He concludes that "Marine Le Pen's voters present a specific profile closer to the 'welfare-chauvinist' type of extreme-right voters as opposed to the original expectation of the authoritarian-capitalist type" (p.73). Similarly, Stockemer and Amengay (this issue) suggest that the FN under Marine Le Pen has been more successful in mobilizing its core electorate among voters with low education, those dissatisfied with democracy and those with a working class background. 


\section{Conclusion and discussion}

This paper has given an account of the economic transformation of the French Front National since the early 1980s. The empirical findings suggest that the FN has significantly changed its socio-economic appeal, moving away from its predominantly right-wing position of the 1980s and towards a leftist location in 2012. Current FN economic policies are increasingly framed by economic egalitarianism. The substantive shift which occurred in 2012 is marked by the acceptance of state regulation and public services, and emphasizes income redistribution. Economic populism is now a dominant mode of FN argumentation which claims to aggregate the interests of all the 'little people' in French society. Since the 1990s, the FN has also accentuated economic nationalism although this move was perceptible in the early 2000s prior to the outbreak of the 2008 financial crisis. Anti-globalization and anti-EU positions dominate the FN's economic agenda and they were central to the party's campaigning in the $2014 \mathrm{EP}$ elections.

The socio-economic transformation of the FN can be seen as the product of both internal and general contextual stimuli. As suggested by Harmel and Janda (1994), "party change is normally a result of leadership change, a change of dominant faction within the party and/or an external stimulus for change" (p.262). The series of FN electoral setbacks between 2007 and 2009 have produced strong incentives for party change, creating also political momentum for Marine Le Pen's strategy of de-demonization. Looking first at internal party dynamics, the rejuvenation of the leadership has been accompanied by the rise of a younger cohort of more pragmatic and power-oriented elites. The appointment of Florian Philippot as strategic campaign director in October 2011 attested to changes in the FN's factional balance ${ }^{13}$. Together with other economic experts within the party, such as Bernard Monot or JeanRichard Sulzer, Philippot has had a strong influence on the new socio-economic line advanced by the FN in the 2012 elections, reflecting his personal left-wing background and contrasting with traditional right-wing economics of Jean-Marie Le Pen's former economic advisor, Jean-Claude Martinez.

Externally, alterations to the FN's economic profile manifest changes that have occurred in the demand-side of radical right politics in France, in particular the growth in working class support for the FN since the late 1980s. This trend has been extensively documented. It has been referred to as 'gaucho-lepénisme' (Perrineau, 1995) or 'ouvriéro-lepénisme' (Mayer, 2002). It exhibits also a strong generational dimension with younger workers showing greater polarization on cultural issues (Gougou and Mayer, 2013, p.163) The findings in this paper confirm that the FN began to revise its neoliberal policies in the mid-1990s, thereby recognizing the necessity to cater to the economic needs and preferences of its new working class voters. Stockemer and Amengay (this issue) demonstrate that the trend towards 'proletarization' of the FN support has accentuated in recent years. As argued by Igounet (2014), FN economic policy moves since the mid-2000s can be seen as strategic attempts by the party to consolidate its electoral strongholds in industrial Northern France, in constituencies characterized by high unemployment and social exclusion.

Beyond the preservation of its core electoral base, however, the magnitude of the FN's shift to the left on the economy seems to indicate a strategic vote maximizing move. Our data support the argument that the FN has substantially altered its programmatic profile to accommodate voter preferences for redistribution and economic regulation in the current policy space of the

\footnotetext{
${ }^{13}$ Recently, Philippot's influence was evidenced by the disciplinary suspension of Jean-Marie Le Pen from the FN in May 2015, following the personal rift between him and his daughter.
} 
crisis. Linking the supply and demand sides of the populist radical right, one important finding in this paper is that the FN has moved towards the median economic voter to the left of the economic axis in $2012^{14}$. This decisive shift corroborates that the FN under Marine Le Pen has been primarily prioritizing short-term maximization of votes, stemming from its status as political outsider and largely contingent on the incentives generated by the electoral system (Ivaldi, 2015). The size of the 2012 economic policy move by the FN lends also support to the argument that niche parties may adjust their policies in response to shifts in mass public opinion, going against the 'policy stability' hypothesis formulated by Adams et al (2006, p.514).

Changes that have occurred in the economic package of the FN in 2012 have not yet brought about a complete transformation of the party's economic agenda. As recent research suggests, the $\mathrm{FN}$ is currently at a political crossroads, showing both continuity and change across several dimensions of party change (Mayer, 2013; Shields, 2013; Crépon et al, 2015). FN economic positions continue to exhibit policy variance, and our data point to the continuation of the party's cultural niche status in the French party system.

Nevertheless, the case study of the French FN exemplifies one possible economic course for the PRR, which might herald a more general reconfiguration of this party family across Europe. Whilst shifting economic positions, the FN has upheld its radical agenda of nativism and authoritarianism on the cultural dimension (Ivaldi, 2015). In the terms of Kitschelt's twodimensional model of party competition, it can be argued that the French FN has breached into the 'socialist-authoritarian' space, which is characteristic of welfare-chauvinist strategies. In the case of France, this move can be thought to be a reaction to the crowding of the capitalist-authoritarian space by the mainstream right since 2007 (Mayer, 2007, pp.444/5; Bornschier, 2010, p.438; Evans and Ivaldi, 2013, pp.101-102).

The electoral revival of the FN seems to indicate that winning PRR strategies are no longer confined to the capitalist-authoritarian sector. The FN may be successfully targeting voters with 'left-authoritarian' political preferences, who are not represented by traditional parties. According to Kitschelt (1995), a significant rise of welfare-chauvinist parties could only be provoked by a severe aggravation of the economy, resulting into a major increase in unemployment across large sectors of the workforce (p.23). Many years ago, Betz (1996) anticipated also "that the radical right [could] in the future abandon market liberalism in favour of a return to Keynesianism and some form of protectionism should the ideological tide turn in Western Europe and elsewhere" (p.717). Our findings indicate that the FN has indeed adapted to changing economic conditions in France, currently showing bright electoral prospects for the 2017 presidential and legislative elections.

\section{References}

Adams, J., Clark, M., Ezrow L. and Glasgow G. (2006) Are niche parties fundamentally different from mainstream parties? The causes and the electoral consequences of Western European parties' policy shifts, 1976-1998. American Journal of Political Science 50(3): 513-529.

\footnotetext{
${ }^{14}$ During the presidential campaign, Marine Le Pen developed a nearly catch-all narrative of "France des oubliés", which targeted a large pool of voters across a variety socio-economic sectors affected by the crisis -i.e. "workers, farmers, students, pensioners, shopkeepers, civil servants or employees".
} 
Achterberg, P., Houtman, D. and Derks A. (2011) Two of a kind? An empirical investigation of anti-welfarism and economic egalitarianism. Public Opinion Quarterly 75(4): 748760.

Akkerman, T. (2015) Immigration policy and electoral competition in Western Europe. A fine-grained analysis of party positions over the past two decades. Party Politics 21(1): 54-67.

Arzheimer, K. (2009) Contextual Factors and the Extreme Right Vote in Western Europe, 1980-2002". American Journal of Political Science 53(2): 259-275.

Benoit, K. and Laver M. (2007) Estimating party policy positions: Comparing expert surveys and hand coded content analysis. Electoral Studies 26(1): 90-107.

Benoit, K. , Laver, M. and Mikhalov S. (2009) Treating words as data with error: Estimating uncertainty in the comparative manifesto measures". American Journal of Political Science 53(2): 49-513.

Benoit, K. and Laver M. (2012) The Dimensionality Of Political Space: Epistemological And Methodological Considerations. European Union Politics 13(2): 194-218.

Betz, H.-G. (1994) Radical Right-Wing Populism in Western Europe. Basingstoke: Macmillan.

Betz, H.-G. (1996), Review: The Radical Right in Western Europe. Political Science Quarterly 111(4): 716-717. .

Betz, H.-G. (2002) Against Globalization: Xenophobia, Identity Politics and Exclusionary Populism in Western Western Europe. In: L. Panitch and C. Leys (eds.), Fighting Identities: Race, Religion and Ethno-Nationalism, London: Merlin, pp.193-210.

Betz, H.-G. and Meret S. (2013), Right-wing Populist Parties and the Working Class Vote: What Have You Done for Us Lately?. In: J. Rydgren (ed.), Class Politics and the Radical Right, London: Routledge, pp.107-121.

Bornschier, S. (2005) « Unis contre la mondialisation? Une analyse de la convergence programmatique des partis populistes de droite européens », Revue internationale de politique comparée 4 (Vol. 12), pp.415-432.

Bornschier, S. (2010) The New Cultural Divide and the Two-Dimensional Political Space in Western Europe. West European Politics 33(3): 419-444.

Brouard, S. , Grossman, E. and Guinaudeau, I. (2012) La compétition partisane française au prisme des priorités électorales. Revue française de science politique 62(2): 255-276.

Budge, I. (1994) A New Theory of Party Competition: Uncertainty, Ideology, and Policy Equilibria Viewed Comparatively and Temporally. British Journal of Political Science 24(4): 443-67.

Budge, I. , Klingemann, H.-D., Volkens, A. and Bara J. (2001) Mapping Policy Preferences. Estimates for Parties, Electors and Governments 1945-1998. Oxford: Oxford University Press.

Crépon, S. , Mayer, N. and Dézé A. (eds.) (2015) Front National : un parti en transition? Paris: Presses de Sciences-Po, forthcoming.

Crittenden, K.S. and Hill R.J. (1971) Coding Reliability and Validity of Interview Data. American Sociological Review 36(6): 1073-1080.

De Koster, W. , Achterberg, P. and Van der Waal J. (2013) The New Right and the Welfare State: On the electoral relevance of welfare chauvinism and welfare populism in the Netherlands. International Political Science Review 34(1): 3-20.

De Lange, S.L. (2007) A New Winning Formula?: The Programmatic Appeal of the Radical Right. Party Politics 13(4): 411-435.

Derks, A. (2006) Populism and the Ambivalence of Egalitarianism. How do the Underprivileged Reconcile a Right Wing Party Preference with their Socio-Economic Attitudes?. World Political Science Review 2(3): 175-200. 
Evans, J. and Ivaldi, G. (2013) The 2012 French Presidential Elections. The Inevitable Alternation, Palgrave MacMillan, French Politics, Society and Culture Series.

Gómez-Reino, M. and Llamazares, I. (2013) The Populist Radical Right and European Integration: A Comparative Analysis of Party-Voter Links. West European Politics 36(4): 789-816.

Harmel, R. and Janda, K. (1994) An Integrated Theory of Party Goals and Party Change. Journal of Theoretical Politics 6(3): 259-287.

Heyer, E. , Cochard, M. , Ducoudré, B. and Péléraux, H. (2013) France : moins d'austérité, plus de croissance. Perspectives 2013-2014 pour l'économie française. Revue de l'OFCE $\mathrm{n}^{\circ} 130$ : 97-153.

Hobolt, S. and Tilley, J. (2013) Blaming Europe? Responsibility without Accountability in the European Union. Oxford: Oxford University Press.

Hooghe, L., Bakker, R., Brigevich, A. de Vries, C., Edwards, E., Marks, G., Rovny, J. and Steenbergen, M. (2010) Reliability and Validity of Measuring Party Positions: The Chapel Hill Expert Surveys of 2002 and 2006. European Journal of Political Research 49(5): 687-703.

Ignazi, P. (2003) Extreme Right Parties in Western Europe. Oxford: Oxford University Press. Igounet, V. (2014) Le Front national de 1972 à nos jours. Le parti, les hommes, les idées. Paris: Seuil.

Ivaldi, G. (2015) A new course for the French radical-right? The Front National and dedemonization. In: T. Akkerman, S. de Lange and M. Rooduijn (eds.) Up to the mainstream? Radical Right-Wing Populist Parties in the New Millennium, Routledge, forthcoming.

Ivarsflaten, E. (2005) The vulnerable populist right parties: no economic realignment fuelling their economic success. European Journal of Political Research 44(3): 465-92.

Kim, H. and Fording, R.C. (1998) Voter ideology in Western Democracies, 1946-1989”. European Journal of Political Research 33(1): 73-97.

Kitschelt, H. (1994) The Transformation of European Social Democracy. Cambridge: Cambridge University Press.

Kitschelt, H. , in collaboration with McGann, A.J. (1995) The Radical Right in Western Europe. A Comparative Analysis. Ann Arbor, MI: University of Michigan Press.

König, T. , Marbach, M. and Osnabrügge, M. (2013) Estimating Party Positions across Countries and Time-A Dynamic Latent Variable Model for Manifesto Data. Political Analysis 21 (4): 468-491.

Kriesi, H. , Grande, E., Lachat, R., Dolezal, M., Bornschier, S. and Frey, T. (2006) Globalization and the transformation of the national political space: Six European countries compared. European Journal of Political Research 45(6): 921-56.

Lefkofridi, Z. , Wagner, M. and Willmann, J. (2014) Left-Authoritarians and Policy Representation in Western Europe: Electoral Choice across Ideological Dimensions. West European Politics 37(1): 65-90.

Lowe, W. , Benoit, K. Mikhaylov, S. and Laver, M. (2011) Scaling Policy Preferences from Coded Political Texts. Legislative Studies Quarterly 36(1): 123-155.

Marks, G. (ed.) (2007) Special Symposium: Comparing Measures of Party Positioning: Expert, Manifesto, and Survey Data, Special Issue Electoral Studies 26(1): 1-141.

Mayer, N. (2002) Ces Français qui votent Le Pen. Paris: Flammarion.

Mayer, N. (2007) Comment Nicolas Sarkozy a rétréci l'électorat Le Pen. Revue française de Science Politique 57(3/4): 429-445.

Mayer, N. (2013) 'From Jean-Marie to Marine Le Pen: electoral change on the Far Right', Parliamentary Affairs, 66(1): 160-78. 
McDonald, M.D. and Mendes, S.M. (2001) The Policy Space of Party Manifestos. In: M. Laver (ed.) Estimating the Policy Position of Political Actors, London: Routledge, pp.90-114.

McGann, A.J. and Kitschelt, H. (2005) The Radical Right in The Alps. Evolution of Support for the Swiss SVP and Austrian FPO. Party Politics 11(2): 147-171.

Meguid, B.M. (2005) Competition Between Unequals: The Role of Mainstream Party Strategy in Niche Party Success. American Political Science Review 99(3): 347-359.

Meguid, B.M. (2008) Party competition between unequals: Strategies and electoral fortunes in Western Europe. Cambridge: Cambridge University Press.

Meyer, T.M. and Wagner, M. (2013) Mainstream or Niche? Vote-Seeking Incentives and the Programmatic Strategies of Political Parties. Comparative Political Studies 46(1): 12461272.

Meyer, T.M. and Miller, B. (2015) The niche party concept and its measurement. Party Politics 21(2): 259-271.

Mudde, C. (2007) Populist Radical Right Parties in Europe. Cambridge: Cambridge University Press.

Olivera, J. (2014) Preferences for redistribution after the economic crisis. ECINEQ, May, n³34 (http://www.ecineq.org/milano/WP/ECINEQ2014-334.pdf).

Otjes, S. , Lucardie, P. and Voerman, G. (2012) Continuity and change in the social-economic agenda of the PVV. European Sociological Association's Research Network on Political Sociology (RN32) Mid-term conference, University of Milan, 30 November-1 December.

Pellikaan, H. , Van der Meer, T. and De Lange, S. (2003) The Road from a Depoliticized to a Centrifugal Democracy. Acta Politica 38: 23-50.

Perrineau, P. (1995) « La dynamique du vote Le Pen : le poids du 'gaucho-lepénisme' » In: P. Perrineau and C. Ysmal (eds.) Le vote de crise. Paris: Presses de Sciences-Po, pp. 243261.

Rovny, J. (2013) 'Where do radical right parties stand? Position blurring in multi-dimensional competition', European Political Science Review 5(1): 1-26.

Rydgren, J. (2005) Is Extreme Right-Wing Populism Contagious? Explaining the Emergence of a New Party Family. European Journal of Political Research 44(3): 413-437.

Shields, J. (2013) Marine Le Pen and the 'New' FN: A Change of Style or of Substance?. Parliamentary Affairs 66(1): 179-196.

Singer, M.M. (2013) The global economic crisis and domestic political agendas. Electoral Studies 32(3): 404-410.

Stockemer, D. and Amengay, A. (2015) The voters of the FN under Jean Marie Le Pen and Marine Le Pen: Continuity or Change? French Politics forthcoming.

Tiberj, V. (2013) Values and the Votes from Mitterrand to Hollande: The Rise of the Twoaxis Politics. Parliamentary Affairs 66(1): 69-86.

Van der Brug, W. and Van Spanje, J. (2009) Immigration, Europe and the 'new socio-cultural dimension. European Journal of Political Research 48(3): 309-334.

Van Kessel, S. (2013) A Matter of Supply and Demand: The Electoral Performance of Populist Parties in Three European Countries. Government and Opposition 48(2): 175199.

Wagner, M. (2012a) 'Defining and measuring niche parties' Party Politics 18(6): 845-864.

Wagner, M. (2012b) When do parties emphasise extreme positions? How strategic incentives for policy differentiation influence issue importance. European Journal of Political Research 51(1): 64-88. 
Zaslove, A. (2008) Exclusion, Community, and a Populist Political Economy: The Radical Right as an Anti-Globalization Movement. Comparative European Politics 6(2): 169189.

\section{Appendix 1. List of FN manifestos and number of coded economic policy pledges}

\begin{tabular}{|l|c|}
\hline Manifesto & N \\
\hline 1981 Tract électoral législatives & 13 \\
\hline 1986: Pour la France: programme du FN & 86 \\
\hline 1988 Passeport pour la victoire & 44 \\
\hline 1993: 300 Mesures pour la renaissance de la France & 170 \\
\hline 1997: Le grand changement: programme du Front national & 51 \\
\hline 2002: Pour un avenir français: programme du Front national & 150 \\
\hline 2007: Programme de gouvernement de Jean-Marie Le Pen & 111 \\
\hline 2012: Programme du Rassemblement Bleu Marine & 89 \\
\hline TOTAL* & $\mathbf{7 1 4}$ \\
\hline
\end{tabular}

* A total of 25 economic policy statements with no clear left-right direction were removed from the analysis $(\mathrm{N}=689)$.

\section{Appendix 2. Specification of the economic dimension (economic policy pledges)}

\begin{tabular}{|l|l|}
\hline Left & Right \\
\hline Government intervention in the economy & Free market competition \\
Public sector expansion & Small government \\
Nationalisations & Privatisations \\
Protectionism & Free trade \\
More government spending & Less government spending \\
Expansion of welfare & Welfare retrenchment \\
Market regulation & Deregulation \\
Redistribution and Keynesian economics & Supply-side economics \\
Labour market control & Labour market flexibility \\
Higher taxes & Lower taxes \\
Trade unions : positive opinion & Trade unions : negative opinion \\
\hline
\end{tabular}


Appendix 3. Assignment of CMP issue categories into aggregate economic and sociocultural issue areas

\begin{tabular}{ll|l}
\hline \multicolumn{2}{l|}{ Socio-Economic } & Socio-cultural \\
\hline per401 & Free Enterprise: Positive & per601 National Way of Life: Positive \\
per402 & Incentives: Positive & per602 National Way of Life: Negative \\
per403 Market Regulation: Positive & per603 Traditional Morality: Positive \\
per404 Economic Planning: Positive & per604 Traditional Morality: Negative \\
per405 Corporatism & per605 Law and Order: Positive \\
per406 Protectionism: Positive & per606 Social Harmony \\
per407 Protectionism: Negative & per607 Multiculturalism: Positive \\
per408 Economic Goals & per608 Multiculturalism: Negative \\
per409 Keynesian Demand Management: Positive & \\
per410 Productivity & \\
per411 Technology and Infrastructure: Positive & \\
per412 Controlled Economy: Positive & \\
per413 Nationalisation: Positive & \\
per414 Economic Orthodoxy & \\
per415 Marxist Analysis: Positive & \\
per416 Anti-Growth Economy: Positive & \\
per504 Welfare State Expansion & \\
per505 Welfare State Limitation & \\
per506 Education Expansion: Positive & \\
per507 Education Expansion: Negative & \\
\hline
\end{tabular}

Appendix 4. Social and economic sub-policy domains (economic policy pledges)

\begin{tabular}{|l|l|}
\hline Economic policy & Social policy \\
\hline Budgetary policies & Child care \\
Economic planning & Education \\
Incentives & Eldercare and pensions \\
Market regulation & Health \\
Price control & Social housing \\
Protectionism & Social security schemes \\
Technology and infrastructure & Unemployment insurance \\
Wage and tax policies & Welfare \\
\hline
\end{tabular}

\section{Acknowledgments}

I am very grateful to Daniel Stockemer at the University of Ottawa and to Sarah de Lange at the University of Amsterdam for their constructive comments on earlier versions of this paper. I wish also to thank the two anonymous referees for their comments and suggestions. All errors or misinterpretations are of course my sole responsibility. 